\title{
BIBECHANA
}

ISSN 2091-0762 (Print), 2382-5340 (Online)

Journal homepage: http://nepjol.info/index.php/BIBECHANA

Publisher: Department of Physics, Mahendra Morang A.M. Campus, TU, Biratnagar, Nepal

\section{Analysis of Aerosol Optical Depth and Angstrom Exponents over an AERONET site at Pokhara, Nepal}

\author{
Jeevan Regmi ${ }^{1 *}$, Khem N Poudyal ${ }^{2}$, Amod Pokhrel $^{3}$, Madhu Gyawali ${ }^{4}$, Anthony Barinelli ${ }^{5}$, \\ Rudra Aryal ${ }^{5}$ \\ ${ }^{1}$ Central Department of Physics, Tribhuvan University Kirtipur, Nepal \\ ${ }^{2}$ Dept. of Applied Sciences, Institute of Engineering Tribhuvan University, Lalitpur, Nepal \\ ${ }^{3}$ University of California Berkeley, California, USA \\ ${ }^{4}$ San Jacinto College, South Campus, 13735 Beamer Rd, Houston, TX 77089 \\ Franklin Pierce University, 40 University Drive, Rindge, NH, USA \\ *Email: jsregmi28@gmail.com
}

Article Information:

Received: June 14, 2020

Accepted: July 27, 2020

Keywords:

Aerosol

Aerosol optical depth

Angstrom exponent

Monthly mariations

\begin{abstract}
The monthly variability of Aerosol Optical Depth at $0.50 \mu \mathrm{m}\left(\mathrm{AOD}_{0.50}\right)$ and Ångström exponents (AE) based on spectral AODs over an Aerosol Robotic Network (AERONET) site Pokhara, are analyzed by using aerosol data of the year 2017. The $\mathrm{AOD}_{0.50}$ are characterized by low average values $(0.21 \pm 0.12)$ in monsoon, and highest values in pre- monsoon $(0.67 \pm 0.14)$ followed by winter $(0.46 \pm 0.28)$ and post- monsoon $(0.33 \pm .02)$ with an overall mean of $0.43 \pm 0.02$. The average AE obtained by using AODs at $0.44 \mu \mathrm{m}$ and $0.87 \mu \mathrm{m}$ are $1.20 \pm 0.04$ in pre- monsoon, $1.37 \pm 0.05$ in monsoon, $1.41 \pm .01$ in post- monsoon, and $1.37 \pm 0.07$ in winter with an annual average value of $1.35 \pm 0.08$. These overall variations of $\mathrm{AE}$ indicate that the majority of aerosol loading during the study period was mixture of fine and coarse mode aerosols and the influence of anthropogenic aerosols. The monthly average AOD suggest low aerosol loading in the months of the monsoon season (June to September) than other months of pre-monsoon season (March to May) and post-monsoon season (October and November).
\end{abstract}

DOI: https://doi.org/10.3126/bibechana.v18i1.29448

This work is licensed under the Creative Commons CC BY-NC License. https://creativecommons.org/licenses/by-nc/4.0/

\section{Introduction}

Aerosols are fine solid or liquid particles suspended in the atmosphere, which are embedded by anthropogenic and natural processes, have a strong contribution to perturb the overall solar radiative forcing [1-3]. Hence, the sources, nature of aerosols, and its climatic impact are a topic of 
significant interest in the climate. Commonly known natural aerosols are dust, sea salt, forest exudates, while anthropogenic aerosols are particulate air pollutants produced from human activities [4]. The importance of studying and measurement of aerosol physical, optical, and chemical properties have increased dramatically since the last few decades as aerosol loading is significantly growing due to urbanization and industrialization, high population density, or biomass burning.

The atmosphere over the urban areas contains a concentration of particles with diameters from a few nanometers to around 100 micrometers produced mainly from a combination of primary particulate emissions from transportations, industries, power generation, and natural sources, and gases to particles conversion [5, 6]. Aerosol particles from combustion sources, such as automobiles, wood burning, and power generation, can be small and are considered up to the size range of 1 micrometer $(\mu \mathrm{m})$. The variability of climate is associated directly with aerosols by scattering and absorbing solar radiation and indirectly by modifying cloud properties [7]. Most of the aerosols are scattering type and cause a cooling effect but some aerosols like black carbon, mineral dust and few organic carbons are absorber of radiation which causes warming effect in the atmosphere [8]. The aerosol produced by human activities has also contributed significantly to climate change $[9,10]$. The analysis of aerosol optical properties along with meteorological parameters such as precipitation, relative humidity will give a picture of aerosol types over the aerosol observation sites [11-13]. Ground-based measurement and analysis of aerosol optical properties are important for the quantitative measure of the extinction of solar radiation by aerosol scattering and absorption. Since the last two decades, the direct measurement of aerosol optical properties from ground-based is increasing worldwide. The Aerosol Robotic Network (AERONET) is one of the network which provides long-term aerosol optical data in many different areas of the world, and it has also established in Pokhara. This site is one of the fast urbanizing cities of Nepal with a lot of construction works, growing industrialization and rapid increase in population[14][2]. It causes to deposit anthropogenic aerosols in the atmosphere which requires a systematic, continuous and long term analysis of physical and chemical properties[15]. But there are very few studies in this region to address the impact of aerosol on climate change, crop productivity, visibility and human health. This work provides an overview of aerosol type by the analysis of Aerosol Optical Depth (AOD) and Angstrom Exponents (AE). A number of previous studies have classified aerosol types from ground based observations and remote sensing from satellites[16,17]. The spectral variation of AOD which can be characterized by Angstrom's parameters gives an idea of particle size and aerosol loading in the atmosphere [18, 19].

\subsection{Theoretical background}

The aerosol characteristics are commonly determined by using the Angstrom's parameters, $\alpha$ and $\beta[20]$ and are related to AOD as;

$\tau(\lambda)=\beta \lambda^{-\alpha}$

where $\alpha$ is the wavelength exponent that represents columnar aerosol size distribution in the atmosphere and used as a qualitative indicator of aerosol particle size and chemical composition. Angstrom exponent values greater than 2 indicate small particles associated with combustion byproducts, and values less than 1 indicate large particles $[21,22]$ like sea salt and soil dust. The detection of high values of $\alpha$ is always associated with the small anthropogenic particles [23]. $\beta$ is the turbidity coefficient that shows the aerosol number concentration in the vertical column of the atmosphere. The value of $\beta$ generally varies from 0.0 to 0.5 . The atmosphere is clean when $\beta$ is less than 0.1 and turbid when it is greater than this. $\alpha$ at wavelengths $0.34,0.38,0.44,0.5,0.67,0.87$, and $1.02 \mu \mathrm{m}$ are sensitive to the volume fraction of 
aerosols with radii less than $0.6 \mathrm{~mm}$ but not to the fine mode effective radius. Long wavelengths $0.67 \mu \mathrm{m}$ and, $0.87 \mu \mathrm{m}$ are sensitive to fine mode volume fraction of aerosols, but not fine mode effective radius, while short wavelengths $0.38 \mu \mathrm{m}$ and, $0.44 \mu \mathrm{m}$ are sensitive to the fine mode effective radius but not the fine mode volume fraction [24].

At a wavelength, $\lambda=1 \mu \mathrm{m}$, we have $\tau(\lambda)=\beta$, which is related to the aerosol column burden.

The linear equation in logarithmic format is given by

$\ln \tau(\lambda)=\ln \beta-\alpha \ln \lambda$

Equation 2 gives the values of Angstrom's parameters $\alpha$ and $\beta$ by least square analysis.

\section{Experiments and Discussion}

\section{Research Site and Instrumentation}

The observation site Pokhara is one of the important geophysical cities and an important tourist destination of Nepal. It is situated at an altitude of $800.0 \mathrm{~m}$ above the sea level and about $200 \mathrm{~km}$, by road, west of the capital city, Kathmandu. The valley is surrounded by hills about 1000-2000 $\mathrm{m}$ high. The elevation rises from 800.0 $\mathrm{m}$ to over $7500.0 \mathrm{~m}$ over an aerial span of $25.0 \mathrm{~km}$. Pokhara is the region of highest precipitation rates in the country ( $3350 \mathrm{~mm} /$ year to $5000 \mathrm{~mm} /$ year). Due to this sharp rise in altitude, the climate of the city is sub-tropical; however, the elevation keeps the temperatures moderate [25]. Summers are humid and mild, and most precipitation occurs during the monsoon season (July - September), winter and spring skies are generally clear and sunny. The mixing of dry westerly air masses with heated moist air masses from the Bay of Bengal produces strong convection over the Pokhara Valley, and thus results in strong updrafts. These strong convective activities are frequent in the premonsoon and monsoon seasons but do not occur during the winter season [26].
AErosol RObotic NETwork (AERONET), a federation of ground-based remote sensing aerosol networks established by NASA and PHOTONS, site in Pokhara is situated on the rooftop of hotel Sangrila, which is near to Pokhara Airport and uses (https://aeronet.gsfc.nasa.gov/cgi-

bin/draw_map_display_inv_v3).CIMEL

Sunphotometer, which is a ground-based device to measure vertical profiles, as shown in the figure 1.

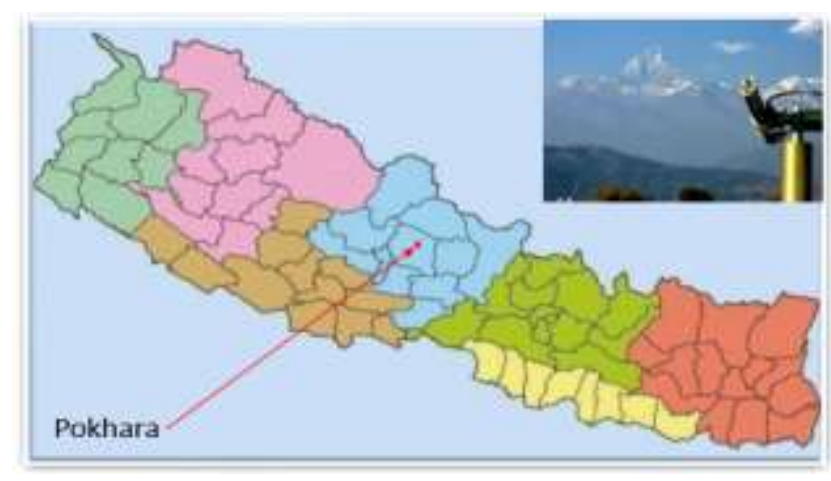

Fig. 1: Map of Nepal showing the location of Pokhara (Red icon) (obtained from https://www.google.com/url:

nepalforeignaffairs.com). The Sunphotometer used for the study is shown in inset. (Photo: Arnico Panday)

CIMEL sun and sky radiometer operate in two modes, direct sun measurements at $0.34 \mu \mathrm{m}, 0.38$ $\mu \mathrm{m}, 0.44 \mu \mathrm{m}, 0.50 \mu \mathrm{m}, 0.675 \mu \mathrm{m}, 0.87 \mu \mathrm{m}, 1.02$ $\mu \mathrm{m}, 1.64 \mu \mathrm{m}$ wavelengths and sky measurements at $0.44 \mu \mathrm{m}, 0.675 \mu \mathrm{m}, 0.87 \mu \mathrm{m}, 1.02 \mu \mathrm{m}[3,26]$. This radiometer makes direct Sun measurements with a $1.2^{\circ}$ full field of view every $15 \mathrm{~min}$. These solar extinction measurements were used to compute aerosol optical depth (AOD), which were automatically computed by using software and are available in the AERONET website. $0.94 \mu \mathrm{m}$ channel is used to retrieve total precipitable water in centimeters. A study has reported the estimated uncertainty in computed AOD approximately \pm 0.01 to \pm 0.02 , which is spectrally dependent with higher errors in the UV region [12]. These data are available on the AERONET website, and since now, we name it as AERONET data. Level 2 
AERONET aerosol optical data are cloud-screened and are used in this study. Since the data are cloud screened and quality assured, data will not be available during cloudy days and when the sensor is wet. For this reason it is very difficult to obtain data during monsoon season.

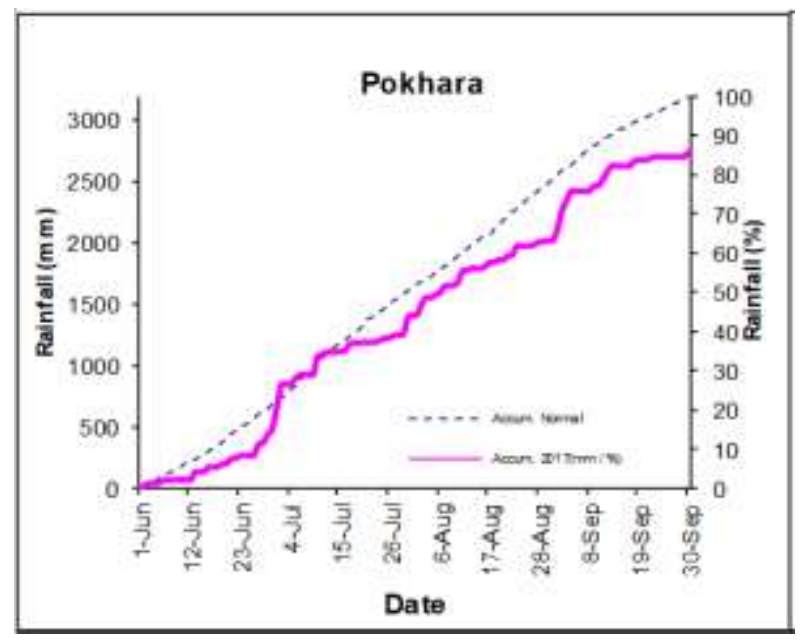

Fig. 2: Accumulated Rainfall during Monsoon 2017 as monitored by DHM, Nepal. The plot is retrived from website of DHM weather on 7/21/2020.

http://www.dhm.gov.np/uploads/getforecast/17972 $\underline{20298 \text { sep } \% 202017 \text { final.docx }}$

As reported by DHM Nepal, the average rainfall during monsoon season (June, July, August and September) are $670 \mathrm{~mm}, 932.5 \mathrm{~mm}, 767 \mathrm{~mm}$ and $714.2 \mathrm{~mm}$ respectively. The average maximum and minimum temperature during the monsoon season were 30.97 and 22.57 respectively. The annual rainfall in the year 2017 was $3743.3 \mathrm{~mm}$. It means a significant amount of rainfall takes place in the monsoon season that can easily flush out larger aerosol particles from the atmosphere causing a larger drop in the value of AOD.

Angstrom exponents, which were obtained by two pairs of wavelengths $0.44 \mu \mathrm{m}$ and $0.87 \mu \mathrm{m}$ are analyzed. Daily averaged aerosol optical depth at $0.50 \mu \mathrm{m}, \mathrm{AOD}_{0.50}$ and angstrom exponents based on wavelengths ranges, $0.40 \mu \mathrm{m}$ to $0.87 \mu \mathrm{m}$ are downloaded from AERONET Pokhara site and analyzed for different months.

\section{Results}

\subsection{Variability of $\mathrm{AOD}_{\mathbf{0 . 5 0}}, \mathrm{AE}$ coefficients and Precipitable Water}

The time series of daily averaged aerosol optical properties, namely $\mathrm{AOD}$ at $0.50 \mu \mathrm{m}\left(\mathrm{AOD}_{0.50}\right)$, calculated Ångström exponents (AE) in a broadband $(0.44 \mu \mathrm{m}-0.87 \mu \mathrm{m})$ and precipitable water $(\mathrm{PW})$ in $\mathrm{cm}$, from January to December of 2017 are presented in figure $2(\mathrm{a}, \mathrm{b}$ and $\mathrm{c})$. The monthly averages of $\mathrm{AOD}_{0.50}, \mathrm{AE}$, and $\mathrm{PW}$ (in $\mathrm{cm}$ ) along with monthly standard deviation are presented in Table 1. It shows that aerosol loading is strong in the months from March to May with significant fine particles. Angstrom exponent data indicate the approximation of the dominant size of fine particles in aerosol loading in all seasons. For our general reference we considered the threshold value of $\mathrm{AOD}$ and $\mathrm{AE}$ for nearby region (Delhi) for anthropogenic, mixed type, biomass burning and dust were taken as 0.3-1.3 and >0.9, 0.4-0.7 and < 0.9 , > 1.3 and $>0.8$, and $>0.7$ and $<0.6$ respectively [27,28]. The significant standard deviation in the AOD and $\mathrm{AE}$ represents for the different types of particulate components loading into the atmosphere $[19,29]$. As expected in the monsoon period (June to September), the air is clean with low and stable AOD. In the rainy season, in which we find a large amount of PW in the atmosphere (Table 1), the monsoon period, the reduced values of AOD may have been caused by differences in the production and flushing of aerosol from the atmosphere due to rain between dry and rainy seasons.

Both AOD and AE exhibit a distinct seasonal trend, mainly in the months of pre and post- monsoon seasons. From the end of winter towards premonsoon season (March to May), the AOD has an increasing trend and may be mainly due to the buildup of anthropogenic aerosols, burning of crop residue such as wheat in the regions as this season is the time of harvesting. PW is an essential 
parameter of the atmosphere for the overall climate change. Monthly mean values, along with standard deviations (Table 1), show that PW is decreasing from post- monsoon seasons to the early stage of premonsoon.
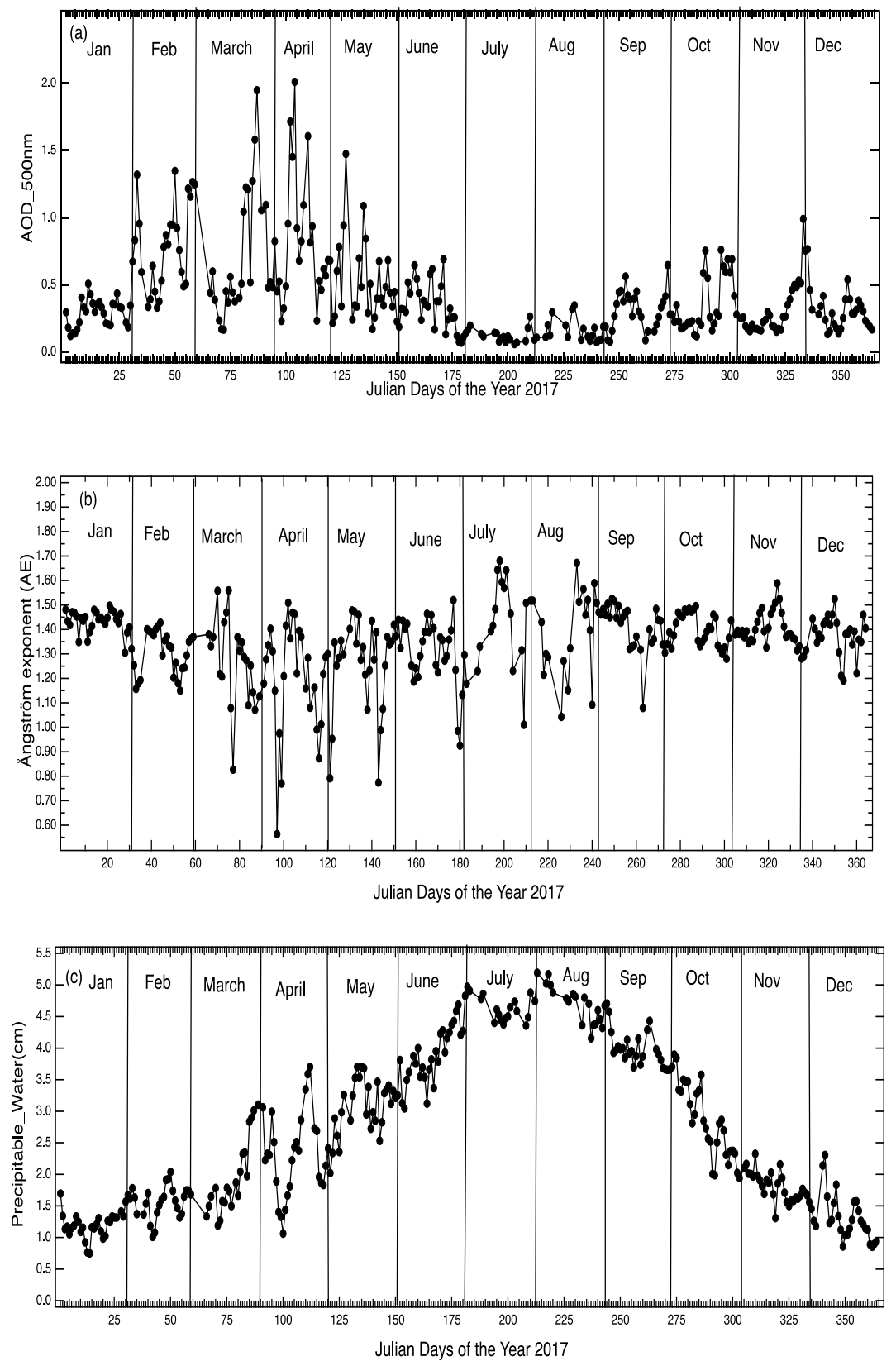

Fig. 2: Time series of daily averaged columnar (a) AOD values at a wavelength $500 \mathrm{~nm}(0.50 \mu \mathrm{m})$, $\mathrm{AOD}_{0.50}$ (b) Ångström exponent (AE) with broad band $0.44 \mu \mathrm{m} / 0.87 \mu \mathrm{m}$ and (c) Precipitable water in cm, measured over Pokhara from Jan to December of 2017. The bottom scale is in Julian day with 1 for January first and 365 for last day of December. 
Table 1. Monthly average of $A O D, A E$ and Precipitable water (PW) and standard deviation in parenthesis for each month. The standard deviation is significant due to daily variability of aerosol optical properties and PW.

\begin{tabular}{|c|c|c|c|}
\hline Months & 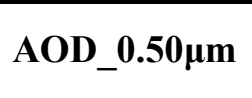 & AE $(0.44 / 0.87)$ & $\begin{array}{c}\text { Precipitable_Water }(P W) \text { in } \\
\text { cm }\end{array}$ \\
\hline Jan & $0.30( \pm 0.12)$ & $1.43( \pm 0.05)$ & $1.21( \pm 0.22)$ \\
\hline Feb & $0.79( \pm 0.33)$ & $1.30( \pm 0.09)$ & $1.56( \pm 0.25)$ \\
\hline March & $0.72( \pm 0.49)$ & $1.27( \pm 0.18)$ & $1.95( \pm 0.59)$ \\
\hline April & $0.79( \pm 0.45)$ & $1.21( \pm 0.22)$ & $2.31( \pm 0.67)$ \\
\hline May & $0.52( \pm 0.31)$ & $1.25( \pm 0.19)$ & $3.06( \pm 0.45)$ \\
\hline June & $0.34( \pm 0.18)$ & $1.31( \pm 0.14)$ & $3.91( \pm 0.46)$ \\
\hline July & $0.12( \pm 0.05)$ & $1.41( \pm 0.18)$ & $4.63( \pm 0.19)$ \\
\hline Aug & $0.16( \pm 0.08)$ & $1.39( \pm 0.18)$ & $4.70( \pm 0.30)$ \\
\hline Sep & $0.31( \pm 0.15)$ & $1.41( \pm 0.09)$ & $3.98( \pm 0.28)$ \\
\hline Oct & $0.36( \pm 0.21)$ & $1.40( \pm 0.06)$ & $2.83( \pm 0.57)$ \\
\hline Nov & $0.31( \pm 0.20)$ & $1.41( \pm 0.06)$ & $1.81( \pm 0.23)$ \\
\hline Dec & $0.30( \pm 0.14)$ & $1.37( \pm 0.08)$ & $1.31( \pm 0.36)$ \\
\hline
\end{tabular}

\subsection{Spectral dependence of AOD}

The spectral values of AOD decrease with an increased value of wavelength of light. The figure 3 shows the strong dependence of AOD at a shorter wavelength and gradually decreases towards the longer wavelengths indicating the presence of fine to coarse aerosol particles. The fine mode particles are responsible for enhancing scattering that causes to make the values of AOD high at a shorter wavelength, whereas coarse mode particles are responsible for lower values of AOD at longer wavelength [19].

It can also be observed from the graph that the variation of AOD with wavelength follows a similar trend for different seasons, as indicated in figure 3 . The average value of AOD is highest at pre-monsoon season followed by winter, postmonsoon, and monsoon season.

The change in curvature in spectral AOD in figure 3 could be due to the presence of more than one type of aerosol in the atmosphere, so characterizing them using a single value of $\alpha$ is only an approximation [30]. The variation of averaged AOD based on different seasons with wavelength in logarithmic scale is investigated by using first order linear fit, given by equation, and calculated angstrom exponents and turbidity parameters.

The Ångström exponent and turbidity parameters for these different seasons based on a single year data are found as $\beta=0.19 \pm 0.01$ and $\alpha=1.16 \pm 0.07$ (winter season), $\beta=0.29 \pm 0.01$ and $\alpha=1.13 \pm 0.04$ (pre-monsoon season), $\beta=0.09 \pm 0.03$ and $\alpha=1.25$ \pm 0.03 (monsoon season), and $\beta=0.13 \pm 0.01$ and $\alpha$ $=1.22 \pm 0.07$ (post-monsoon season). The variation 
of turbidity parameters indicates for the aerosol loadings, and the order of $\beta$ values perfectly matches the variation of AOD values. The Ångström exponents indicate for a significant contribution of fine mode particles. These $\alpha$ values were calculated using the mean spectral aerosol optical depth (AOD) at wavelengths, $\lambda$, from 0.34 $\mu \mathrm{m}$ to $1.64 \mu \mathrm{m}$. On the other hand, the seasonal $\alpha$ based on the spectral AOD at wavelengths ranges $0.44 \mu \mathrm{m}$ to $0.87 \mu \mathrm{m}$ were found as $\alpha=1.36 \pm 0.06$ (winter season), 1.24 0.03 (pre-monsoon season), $1.37 \pm 0.05$ (monsoon season), and $1.40 \pm 0.01$ (post-monsoon season). In our study, $\alpha$ calculated using two different wavelength ranges of AOD shows very little differences, with slightly higher $\alpha$ obtained in the ranges $0.34 \mu \mathrm{m}$ to $1.64 \mu \mathrm{m}$.

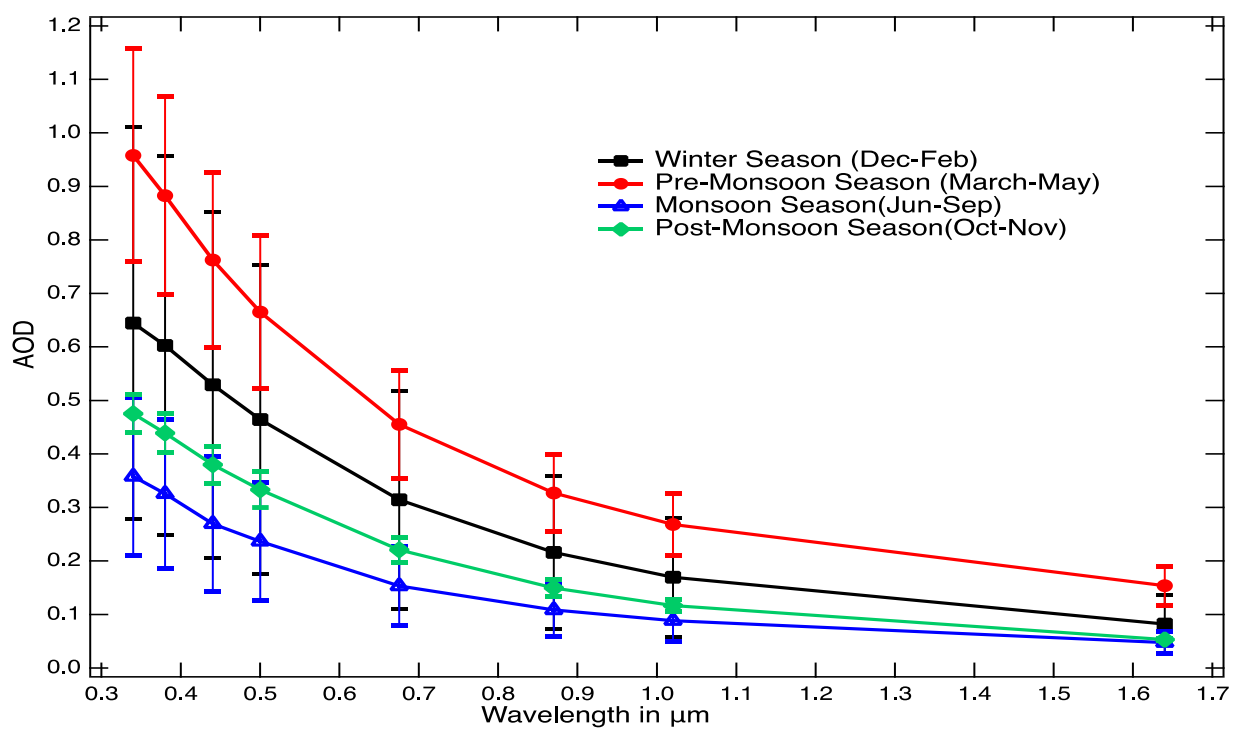

Fig. 3: Spectral Variation of AOD.

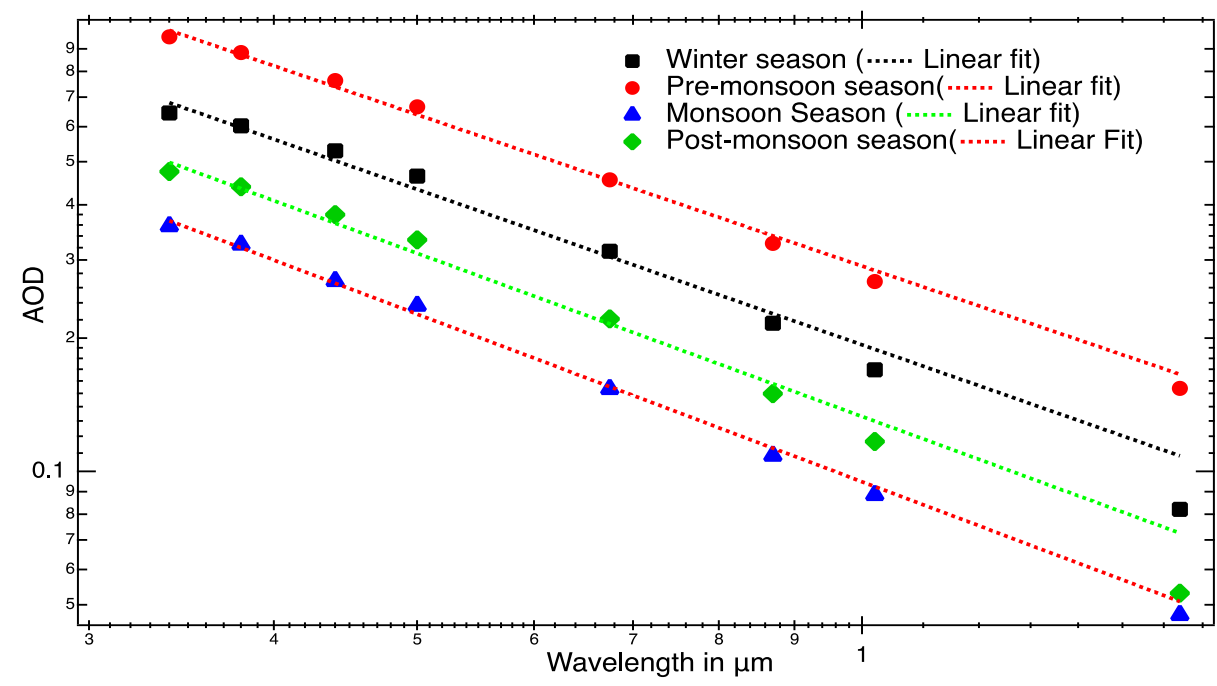

Fig. 4: Spectral variation of the mean aerosol optical depth (AOD) at six wavelengths, $\lambda$, from $0.44 \mu \mathrm{m}$ to $1.64 \mu \mathrm{m}$ for different seasons and linear fit in logarithmic wavelength scale. 


\section{Conclusions}

The monthly averaged AOD over the Pokhara AERONET device data shows that aerosol concentration is lower in the months from July to September than in the pre and post-monsoon season. It is associated with the regular rainfall in the region during this period. This study shows that the lower AOD on these months is due to the heavy rainfall, as indicated by higher precipitable water levels during the monsoon season. The lowest columnar $\mathrm{AOD}$ at $0.50 \mu \mathrm{m}\left(\mathrm{AOD}_{0.50}\right)$ characterize the lowest aerosol loading in monsoon, and highest average values in pre-monsoon followed by winter and post-monsoon. Previous studies suggest that the higher value of AOD during pre-monsoon and post-monsoon is due to the accumulation of aerosol loading from biomass burning and trans-boundary pollution from IGP (Indo Gangetic Plain). AE's Comparison obtained at two wavelength ranges, 0.44 to $0.87 \mu \mathrm{m}$ and 0.34 to $1.64 \mu \mathrm{m}$, indicates that $\mathrm{AE}$ observed in the ultraviolet to infrared ranges can estimate aerosol sizes and shows that the aerosol has comparatively less impact on the infrared region. This analysis presented only oneyear aerosol optical data to represent monthly variation along with seasonal variation. Therefore this study also sees the importance of further analysis of aerosol optical properties by using multi-year aerosol data along with back trajectory analysis of air masses to identify trans-boundary aerosols and source of air pollution over Pokhara.

\section{Acknowledgments}

Authors are thankful to Dr. Arnico Panday, Nepal, and AERONET group of NASA, USA for sun/sky radiometers data (http://aeronet.gsfc.nasa.gov/) from Pokhara site.

\section{Conflicts of Interest}

The authors declare no conflict of interest.

\section{References}

[1] R. P. Aryal, K. J. Voss, P. A. Terman, W. C. Keene, J. L. Moody, E. J. Welton, and B.N. Holben, Comparison of surface and column measurements of aerosol scattering properties over the western North Atlantic Ocean at Bermuda, Atmos. Chem. Phys. 14 (2014) 7617-7629. http://doi.org/10.5194/acp-14-7617-2014.

[2] T. C. Bond, S. J. Doherty, D.W. Fahey, P. M. Forster, T. Berntsen B. J. DeAngelo, M. G. Flanner, S. Ghan, B. Kärcher, D. Koch, S. Kinne, Y. Kondo, P. K. Quinn, M. C. Sarofim, M.G. Schultz, M. Schulz, C. Venkataraman, H. Zhang, S. Zhang, N. Bellouin, S. K. Guttikunda, P.K. Hopke, M. Z. Jacobson, J. W. Kaiser, Z. Klimont, U. Lohmann, J. P. Schwarz, D. Shindell, T. Storelvmo, S. G. Warren, and C. S. Zender, Bounding the role of black carbon in the climate system: A scientific assessment, J. Geophys. Res. 118 (2013) 5380-5552. http://doi.org/doi:10.1002/jgrd.50171

[3] B. N. Holben, T. F. Eck, I. Slutsker, A. Smirnov, J. Sinyuk, A. Schafer, D. Giles, and O. Dubovik. Aeronet's Version 2.0 quality assurance criteria, Proc. SPIE Remote Sens.

Atmos, Clouds, (2006) 6408, 64080Q. https://doi.org/10.1117/12.706524.

[4] William C. Hinds, Aerosol Technology (2nd ed.). Wiley-Interscience, Iqbal Muhammad, An introduction to Solar Radiation, Academic Press, New York (1999).

ISBN 978-0471-19410-1

[5] M. Salby. Fundamentals of Atmospheric Physics, Academic Press, California (1996). ISBN: 9780126151602

[6] J. Seinfeld, and S. Pandis. Atmospheric chemistry and physics: from air pollution to climate change, Wiley, Inc., New Jersey, USA (2006) p. 450.

[7] B. Verheggen and E. P. Weijers, Climate change and the impact of Aerosol: Energy Research Centre of the Netherlands (ECN) (2010) ECN-E--09-095.

[8] G. Myhre, C. E. L. Myhre, B. H. Samset and T. Storelvmo, Aerosols and their Relation to Global Climate and Climate Sensitivity, Nature Education Knowledge 4(5) (2013)7.

[9] O. Boucher, Atmospheric Aerosols Properties and Climate Impacts, Springer, Netherlandes (2015). ISBN978-94-017-9648-4

[10] J. A. Duffie, and W. A. Beckman. Solar engineering of Thermal Processes, Fourth Edition. 2013, John Wile \& Sons, Inc. (2013).

ISBN: 0-471-51056-4. 
[11] S. Fuzzi, U. Baltensperger, K. Carslaw, S. Decesari, H. Denier van der Gon, M. C. Facchini, D. Fowler, I. Koren, B. Langford, U. Lohmann, E. Nemitz, S. Pandis, I. Riipinen, Y.Rudich, M. Schaap, J.G. Slowik, D. V. Spracklen, E. Vignati, M. Wild, M. Williams, and S. Gilardoni, Particulate matter, air quality and climate: lessons learned and future needs, Atmos. Chem. Phys. 15 (2015) 8217-8299. https://doi.org/10.5194/acp-15-8217-2015.

[12] B. N. Holben, T. F. Eck, I. Slutsker, D. Tanre, J. P. Buis, A. Setzer, E. Vermote, J. A. Reagan, Y. J. Kaufman, T. Nakajima, F. Lavenu, I. Jankowiak, and A. Smirnov et al. AERONET -A federated instrument network and data archive for aerosol characterization, Remote Sens. Environ. 66(1) (1998) 1-16 https://doi.org/10.1016/S0034- 4257(98)00031-5.

[13] D. Putero, P. Cristofanelli, A. Marinoni, B. Adhikary, R. Duchi, S. D. Shrestha, G. P. Verza, T. C. Landi, F. Calzolari, M. Busetto, G. Agrillo, F. Biancofiore, P. Di Carlo, A. K. Panday, M. Rupakheti, and P. Bonasoni, Seasonal variation of ozone and black carbon observed at Paknajol, an urban site in the Kathmandu Valley, Nepal, Atmos. Chem. Phys. 15 (2015) 13957-13971. https://doi.org/10.5194/acp-15-13957-2015

[14] R. Gautam, N. C. Hsu, S. C. Tsay, K. M. Lau, B. Holben, S. Bell, A. Smirnov, C. Li, R. Hansell, Q. Ji, S. Payra, D. Aryal, R. Kayastha, and K. M. Kim, "Accumulation of aerosols over the IndoGangetic plains and southern slopes of the Himalayas: Distribution, properties and radiative effects during the 2009 pre-monsoon season," Atmos. Chem. Phys. 11 (24) (2011)12841-12863. https://doi.org/10.5194/acp-11-12841-2011

[15] P. Tian, X. Cao, L. Zhang, N. Sun, L. Sun, T. Logan, J. Shi, Y. Wang, Y. Ji, Y. Lin, Z. Huang, T. Zhou, Y. Shi, and R. Zhang, "Aerosol vertical distribution and optical properties over China from longterm satellite and ground-based remote sensing," Atmos. Chem. Phys. 17 (4) (2017) 25092523. https://doi.org/10.5194/acp-17-2509-2017

[16] O. Dubovik, B. Holben, T. F. Eck, A. Smirnov, Y. J. Kaufman, M. D. King, D. Tanre and I. Slutsker, "Variability of absorption and optical properties of key aerosol types observed in worldwide locations", J. Atmos. Sci. 59 ( 3 ) (2002) 590-608.
2002.

https://doi.org/10.1175/15200469(2002)059<0590: VOAAOP $>2.0 . \mathrm{CO} ; 2$

[17] D. G. Kaskaoutis, K. V. S. Badarinath, S. K. Kharol, A. R. Sharma, and H. D. Kambezidis, "Variations in the aerosol optical properties and types over the tropical urban site of Hyderabad, India”, J. Geophys. Res. Atmos. 114 (22) (2009) $1-20$. https://doi.org/10.1029/2009JD012423

[18] B. N. Holben, D. Tanré, A. Smirnov, T. F. Eck, I. Slutsker, N. Abuhassan, W.W. Newcomb, J. S. Schafer, B. Chatenet, F. Lavenu, Y. J. Kaufman et al."An emerging ground-basedaerosol climatology: Aerosol optical depth from AERONET" J. Geophys. Res. Atmos. 106 ( D11) (2001)1206712097.

[19] T. F. Eck, B. N. Holben, J. S. Reid, O. Dubovik, A. Smirnov, N. T. O’Neill, I. Slutsker and S. Kinne., Wavelength dependence of the optical depth of biomass burning, urban, and desert dust aerosol, J. Geophys. Res. 104

(31) (1999) $333-349$. https://doi.org/10.1029/1999JD900923

[20] A. Angstrom. Techniques of Determining the Turbidity of the Atmosphere, Tellus 13 (1961) 214-223. https://doi.org/10.1111/j.2153- 3490.1961.tb00078.x.

[21] M. Gyawali, W. P. Arnott, K. Lewis, and H. Moosmuller. Photoacoustic optical properties at UV, VIS, and near IR wavelengths for laboratory generated and winter time ambient urban aerosols, Atmos. Chem. Phys. 12 (2012) 2587-2601. https://doi.org/10.5194/acp12-2587

[22] H. Moosmuller, R. K. Chakrabarty, K. M. Ehlers, and W. P. Arnott. Absorption Angstrom coefficient, brown carbon, and aerosols: basic concepts, bulk matter, and spherical particles, Atmos. Chem. Phys. 11 (2011) 1217-1225. https://doi.org/10.5194/acp-11-1217- 2011.

[23] N. T. O'Neill, T. F. Eck, A. Smirnov, B. N. Holben, and S. Thulasiraman. Spectral discrimination of coarse and fine mode optical depth, Journal of Geophysical Research. (2003) 108. https://doi.org/10.1029/2002JD002975.

[24] G. L. Schuster, O. Dubovik, and B. N. Holben. Angstrom exponent and bimodal aerosol size 
distributions, J. Geophys. Res. 111 (2006) D07207, https://doi.org/10.1029/2005JD006328

[25] K. N. Poudyal, B. K. Bhattarai, B. K. Sapkota, B. Kjeldstad, and N. R. Karki. Estimation of Global Solar Radiation using Pyranometer and NILU-UV Irradiance Meter at Pokhara Valley in Nepal. Journal of the Institute of Engineering. 9(1) (2003) 69-78.

[26] A. Singh, K. S. Mahata, M. Rupakheti, W. Junkermann, A. K. Panday, and M. G. Lawrence. An overview of airborne measurement in NepalPart 1: Vertical profile of aerosol size, number, spectral absorption, and meteorology, Atmospheric Chemistry and Physics. 19(1) (2019) 245-258. https://doi.org/10.5194/acp-19-245-2019.

[27] M. Sharma, D. G. Kaskaoutis, R. P. Singh, and S. Singh, "Seasonal variability of atmospheric aerosol parameters over greater Noida using ground sunphotometer observations", Aerosol Air Qual. Res. $14 \quad$ (3) (2014) 608-622. https://doi.org/10.4209/aaqr.2013.06.0219

[28] D. Rupakheti, S. Kang, Z. Cong. M. Rupakheti, L. Tripathee, A. K. Panday and B. N. Holben, "Study of aerosol optical properties over two sites in the foothills of the central himalayas", Int. Arch. Photogramm. Remote Sens. Spat. Inf. Sci. -ISPRS Arch. $42 \quad$ (3) (2018) 1493-1497. https://doi.org/10.5194/isprs-archives-XLII-3-1493-2018

[29] T. F. Eck, B. N. Holben, J. S. Reid, D. M. Giles, M. A. Rivas, R. P. Singh, S. N. Tripathi, C. J. Bruegge, S. Platnick, G. T. Arnold, N. A. Krotkov, S. A. Carn, A. Sinyuk, O. Dubovik, A. Arola, J. S. Schafer, P. Artaxo, A. Smirnov, H. Chen, and P. Goloub. Fog-and cloudinduced aerosol modification observed by the Aerosol Robotic Network (AERONET), J. Geophys. Res. 117(2012)D07206. https://doi.org/10.1029/2011JD016839

[30] R. Pedr'os, J. A. Martinez-Lozano, M. P. Utrillas, J. L. G' omez-Amo, and F. Tena, Columnintegrated aerosol, optical properties from ground-based spectro radiometer measurements at Barrax (Spain) during the Digital Airborne Imaging Spectrometer Experiment (DAISEX) campaigns. J. Geophys. Res. 108 (D18) (2003)4571-4587. https://doi.org/10.1029/2002JD003331 